\title{
How Do Climate and Nonclimatic Variables Influence the Production of Agricultural Staple Crops in Vulnerable Rural Communities in the Bawku Municipality of Northern Ghana?
}

\author{
Rashida Ayumah, ${ }^{1}$ Felix Asante $\left(\mathbb{D},{ }^{1}\right.$ Lawrence Guodaar, ${ }^{2}$ and Gabriel Eshun ${ }^{1}$ \\ ${ }^{1}$ Kwame Nkrumah University of Science and Technology, Geography and Rural Development, \\ College of Humanities and Social Sciences, Faculty of Social Sciences, PMB, University Post Office, Kumasi, Ghana \\ ${ }^{2}$ University of Adelaide, Geography, Environment and Population, Faculty of Arts, School of Social Sciences, Napier, Adelaide, \\ SA 5005, Australia \\ Correspondence should be addressed to Felix Asante; couzon_species@yahoo.com
}

Received 20 September 2019; Accepted 22 April 2020; Published 20 May 2020

Academic Editor: Gábor Kocsy

Copyright (c) 2020 Rashida Ayumah et al. This is an open access article distributed under the Creative Commons Attribution License, which permits unrestricted use, distribution, and reproduction in any medium, provided the original work is properly cited.

\begin{abstract}
We examined the influence of climate (temperature and rainfall) and nonclimatic variables (soil fertility using soil pH and organic matter) on the production of agricultural staple crops (maize [Zea mays L.], millet [Pennisetum glaucum L.], and rice [Oryza sativa L.]) in vulnerable communities in the Bawku Municipality of northern Ghana. Using five selected farming communities as study sites, multiple datasets were obtained from primary and secondary sources. Participatory approaches together with questionnaires were used as data collection tools to quantify and qualify climate (temperature and rainfall) and nonclimatic variables (soil fertility using soil $\mathrm{pH}$ and organic matter) and crop production. The Mann-Kendall trend test results indicate a significant variation in annual rainfall for the 15-year period (1999 to 2013) with a relatively stable mean temperature variation in the Municipality. The results of the multiple regression indicate that climatic and nonclimatic factors, particularly rainfall, soil $\mathrm{pH}$, and organic matter have a significant positive effect on maize, millet, and rice when other factors are held constant. We conclude that to ease the burden of climate on production, better irrigation facilities be provided for the Municipality and weather forecasting information on the pending growing season be made available to farmers to enable them take informed decision. Also, policy on climate adaptation should take into account the interaction of external drivers of climate and nonclimatic variables to better build farmers' resilience for food security at the local level.
\end{abstract}

\section{Introduction}

The dynamic oscillation of the Earth's climate is a reality. The variation in the climate system across spatial scales is what is termed as climate variability (henceforth CV) [1]. Under global warming, it is projected that climate variables including temperature and rainfall will vary with disproportional effects on agriculture [2-4]. The complexity of CV remains a cardinal challenge for sustainable agriculture and food security [4-11]. Regionally, Sub-Saharan Africa illuminates high level of vulnerability to food insecurity due to the considerable impacts CV has on agricultural systems which remain the "oxygen" that supports the economies.
Low precipitation considerably affects agricultural systems of many SSA countries [12]. Many staple crops have suffered drastic declines which consequently affected the livelihood of smallholder farmers in many parts of SSA including Ghana [13]. The big question is how susceptible food crop production might be to the interaction of climate and nonclimatic variables? Scholarship on how specific crops are adversely influenced by CV is abound in many parts of the world. For instance, Osbourne and Wheeler [9] indicate that, globally, between the years 1960 and 2009, rice yields declined considerably due to low rainfall. Scientific evidence suggests that, in many agricultural landscapes, crop yields are expected to fall between $10 \%$ and $20 \%$ because of 
increased CV risks [14]. In a related analysis, the IPCC estimated that 34 million to over 600 million are likely to suffer from starvation by 2080 [15]. Thus, it is increasingly relevant to ascertain the dynamics of how climate variables interact to influence crop production in order to develop strategic policies that will be sustainable for food security [16]. Apart from rainfall, high temperature is another climate determinant of many agricultural crops [4]. It is estimated that for each $1^{\circ} \mathrm{C}$ rise in average temperature, the income of farmers will potentially reduce by about $10 \%$ [5]. This may likely be intensified in many Third World countries due to their limited ability to adapt. Consequently, the economic hardship of farmers could intensify as a result of the impacts on livelihoods [17]. The myriad of impacts according to the IPCC [1] would be experienced differently across the continent due to other socioeconomic challenges.

Nonclimatic factors are also recognized as important factors that influence crop yield $[18,19]$. Technological and management factors such as irrigation, crop varieties, and fertilizer application are suggested as important nonclimatic factors that can directly or indirectly influence crop production, particularly maize [20]. Soil fertility is argued as an important nonclimatic driver that can considerably affect crop productivity, especially grains [19]. However, the consideration for nonclimatic variables and their concomitant risks on agricultural systems, particularly crop production is largely given little attention [21]. It is suggested that the interface of climate and nonclimatic factors are disproportional in terms of their impacts on crop production [22]. Thus, exploring how these variables influence different staple crops is important, particularly in SSA and Ghana where many people depend on agricultural crop production for their livelihood.

Ghana has not been exempted from the phenomenon of $\mathrm{CV}$. This is because of the level of exposure and sensitivity of agricultural systems to CV in the country. Rainfall patterns have shifted, coupled with protracted drought spells and increased temperature conditions [23]. These manifestations are considerably conspicuous in the northern sector with more expected future variations [6]. This situation will significantly constrain agricultural systems in many parts of Ghana, particularly the northern sector $[8,24]$. Since the agricultural sector employs a large proportion of the people of Ghana, any uncertainties due to CV could, therefore, cause great devastation to the economy of the country. The inadequate rainfall in 1982-1983 is a testament to how drought destroyed most crops and negatively affected more than 12 million people in the country [25]. Furthermore, in 2007, northern Ghana was wrecked by marauding flood waters that affected three hundred and seventeen thousand $(317,000)$ people with the Central Gonja District being described as an environmental calamity; because, about twenty-six thousand eight hundred and twenty-two $(26,822)$ acres of farmlands were destroyed [26]. Crop production data for staples such as maize (Zea mays L.), millet (Pennisetum glaucum L.), and rice (Oryza sativa L.) in Northern Ghana have been declining since the year 2010/2011 due to low rainfall [27].
Extensive research on CV risks on crops in Ghana has indicated the threats $\mathrm{CV}$ poses to agricultural crops $[23,24,28]$. However, little information is available in the literature on how climate and nonclimatic predictors, particularly temperature, rainfall, soil $\mathrm{pH}$, and organic matter interact to dynamically influence the production of agricultural staple crops in vulnerable rural communities in northern Ghana. The challenge is, therefore, to investigate and fill this knowledge gap for a good policy link aimed at effective adaptative capacity building to mitigate the influence of climatic and nonclimatic risks on staple crop production. Specifically, this paper aims to quantify and qualify how climate and nonclimatic variables influence the production of agricultural staple crops with emphasis on maize (Zea mays L.), millet (Pennisetum glaucum L.), and rice (Oryza sativa L.) cultivated in many vulnerable rural communities in the Bawku Municipality of northern Ghana.

\section{Materials and Methods}

2.1. Study Site. The Bawku Municipality is located in the extreme north-eastern part of Ghana and is one of the two Municipalities in the Upper East Region of Ghana (Figure 1). It lies between latitudes $10^{\circ} 40^{1}$ and $11^{\circ} 11^{1}$ north of the Equator and longitudes $0^{\circ} 18^{1}$ west and $0^{\circ} 6^{1}$ east of the Greenwich Meridian. The Bawku municipality has a total land size of about $247.23720 \mathrm{~km}^{2}$. The municipality is bounded to the north by Burkina Faso, to the south by the Garu-Tempane District, to the west by Binduri District, and to the east by Pusiga District [29]. The Municipality is located within the Sudan Savanna zone with variable rainfall pattern and unfavourable soil characteristics to support agriculture.

The research covered five communities in the Bawku Municipality. These are Mognori, Kuka, Gosezi, Zabugu, and Gentiga communities. The choice on the study sites was informed by the vulnerability of the Municipality to CV and staple insecurity.

2.2. Data Collection. We employed both qualitative and quantitative data in the study for a comprehensive understanding of the issues. The two datasets were obtained from primary and secondary sources using questionnaires, focus group discussions (FGDs), and structured interview protocols. Questionnaires were administered in a face-to-face manner to food crop farmers. Focus Group Discussions were carried out in each community to generate conversations that uncover individual opinions regarding the effects of $\mathrm{CV}$ on food crop. Structured interviews were employed to obtain additional information from officials of the Ministry of Food and Agriculture (MoFA), Savanna Agriculture Research Institute (SARI), for their direct contact with farmers in the Municipality and the Ghana Meteorological Agency (GMA). The purpose was to explain and verify the findings from the questionnaires. The study relied on documented records of monthly observations of climate variables compiled by the GMA for a period of 15 years. The use of a 15 -year data was considered as adequate because consistent collation of data over periods of 15 years or more according to Hochman et al. 


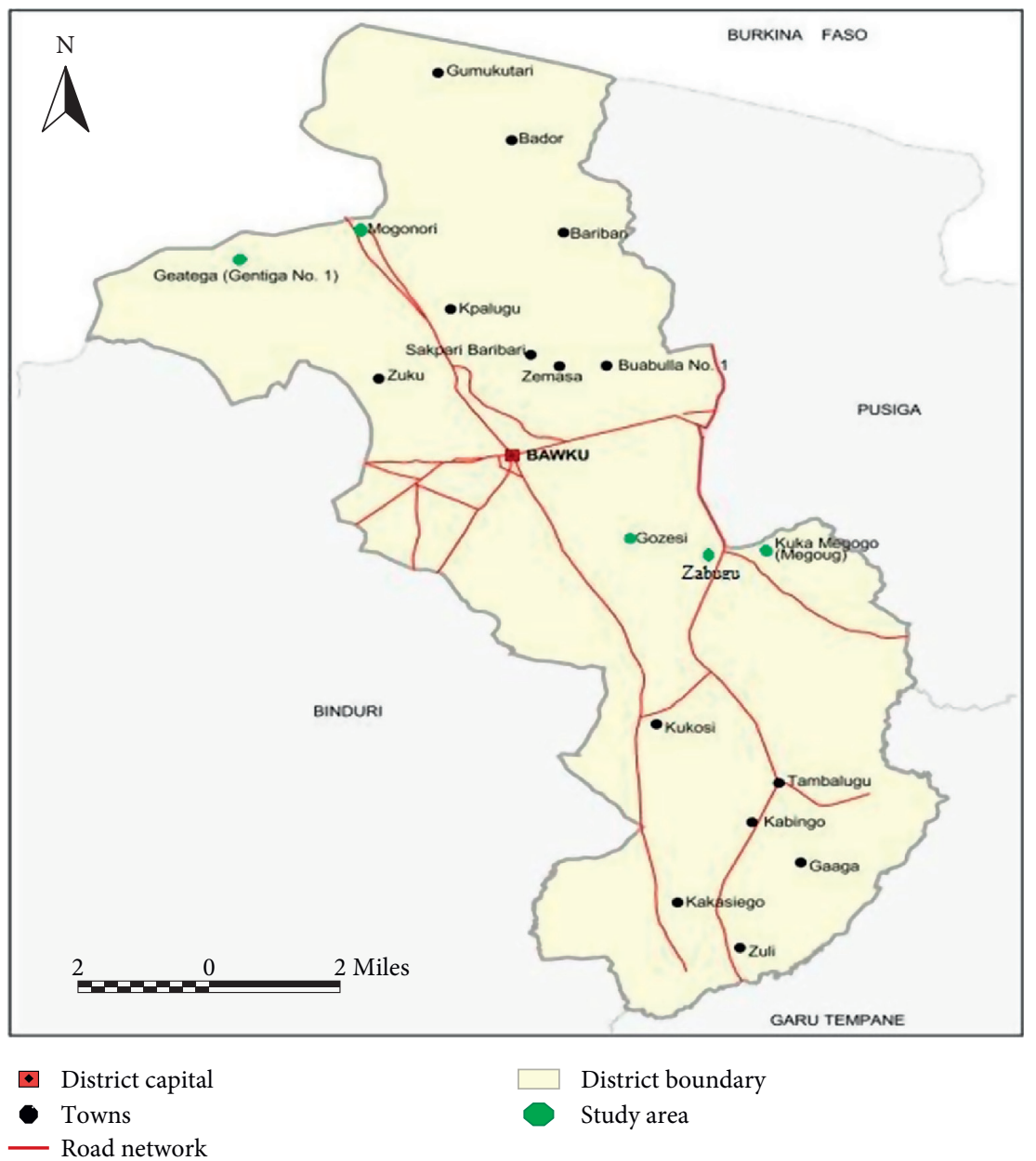

Figure 1: Map of Bawku Municipality showing the study communities (source: Bawku Municipal Assembly (2015)).

[30] provides a good basis for crop yield analysis in relation to $\mathrm{CV}$. The climate variables used for the study were temperature and rainfall $[1,5]$. Production data on key food crops; maize (Zea mays L.), millet (Pennisetum glaucum L.), and rice (Oryza sativa L.) in the study area from 1999 to 2013 were also obtained from MoFA in Bawku for analysis. In addition, data on soil fertility in the Bawku Municipality over the period under investigation were obtained from the Soil Research Institute (SRI) in Kumasi. To assess which soil fertility variables are important in explaining the variations on crop yield, a correlation analysis was performed on staple crops and soil fertility variables (soil $\mathrm{pH}$, organic matter, nitrogen, and phosphorus). Organic matter was found to be correlated with maize and millet while soil $\mathrm{pH}$ was correlated with rice. Soil $\mathrm{pH}$ was therefore used as a proxy for soil fertility in rice production and organic matter as a proxy for soil fertility in millet and maize production.

The study participants were sampled simple randomly and purposively. The random sample of the survey participants were based on the model proposed by Kasiulevičius et al. [31]:

$$
n=\frac{N}{1+N(e)^{2}}
$$

where $e=$ deviation of sampling, $N=$ population size and $n=$ sample size.

The model has a confidence level of $95 \%$ and a $5 \%$ error margin [31]. The sample frame of the study consisted of a master list of household farmers of the five communities obtained from the Planning Department of the Bawku Municipal Assembly. A total of 214 household farmers were randomly sampled for the survey across the study communities (Table 1).

2.3. Data Analysis. The quantitative data obtained from the farmers were processed and analysed using descriptive statistics. Frequency tables, cross-tabulations, bar graphs, and pie charts were used as tools for representing the survey data. Also, time series analysis was used to examine the trend in annual maximum and minimum temperatures as well as rainfall over the 15-year period (1999 to 2013) with the help of MAKESENS Excel Software. The magnitude of the trends of the climate variables was tested by the Mann-Kendall trend test. The trend was quantified using Sen's slope formula:

$$
Q_{i}=\frac{x_{j}-x_{k}}{j-k}, \quad i=1,2,3, \ldots, N, j>k
$$


TABLE 1: Sample size of selected communities.

\begin{tabular}{lcc}
\hline Community & $\begin{array}{c}\text { Household } \\
\text { population }\end{array}$ & $\begin{array}{c}\text { Sample size for } \\
\text { communities }\end{array}$ \\
\hline Mognori & 61 & 51 \\
Zabugu & 66 & 55 \\
Gozesi & 52 & 47 \\
Kuka & 35 & 31 \\
Gentiga & 33 & 30 \\
Total & $\mathbf{2 4 7}$ & $\mathbf{2 1 4}$ \\
\hline
\end{tabular}

Source: GSS, 2010.

where $x_{\mathrm{j}}$ and $x_{\mathrm{k}}$ values are time $j$ and $k$, respectively. The median of these $N$ values of $Q_{i}$ is Sen's estimator of the slope. Also, the variability of rainfall, temperature, and food crop production was analysed using the coefficient of variation. This was determined by dividing the standard deviation by the mean.

A multiple regression model (Ordinary Least Square procedure) was used to analyse the influence of climatic (temperature and rainfall) and nonclimatic (soil $\mathrm{pH}$ and organic matter) factors on three major food crops, maize (Zea mays L.), millet (Pennisetum glaucum L.), and rice (Oryza sativa L.), over the 15-year period (1999 to 2013) by holding all other confounding factors constant through the help of the Predictive Analytic Software (PASW) version 21. The multiple regression model was used due to the fact that it has been widely used in analyzing the effects/impacts of climate variability/change on food crop production [7, 32]. To ensure the robustness and validity of the estimates of the multiple regression model, the underpinning assumption of normal distributions, homoscedasticity, and serially uncorrelated errors were tested using Jacque-Bera, Breusch-Pagan-Godfrey test, and Breusch-Godfrey Serial Correlation LM Test (Antonakis and Deitz, 2011 cited in Ballance) [33]. The level of significance for the study was set at 0.05 . The linear regression model used is similar to the model used by Onoja and Ajie [34] to analyse how food crops respond to climate variability and microeconomic policies reform in Nigeria. The model is presented as

$$
Y=\beta o+\beta_{1} X_{i}+\beta_{2} X_{i}+\beta_{3} X_{i}+\cdots+\beta_{k} X+\mu i,
$$

where $Y$ is the dependent variable; $X$ is the independent variable while $\mu$ is the stochastic error term, and $\beta$ o is the intercept of the model. Natural logarithms of the variables were taken to strengthen out exponential growth pattern and reduce the potential heterogeneity of variance of error terms; that is, to stabilize variance [35].

$$
\begin{aligned}
\text { LnRice }_{i} & =\beta o+\beta_{1} \ln R A i+\beta_{2} \ln T E i+\beta_{3} \ln S P H i+\mu_{i}, \\
\text { LnMillet }_{i} & =\beta o+\beta_{1} \ln R A i+\beta_{2} \ln T E i+\beta_{3} \ln \text { ORGi+ } \mu_{i}, \\
\text { LnMaize }_{i} & =\beta o+\beta_{1} \ln R A i+\beta_{2} \ln T E i+\beta_{3} \ln \text { ORGi+ } \mu_{i},
\end{aligned}
$$

where $\mathrm{RA}=$ annual rainfall in millimeters in the Bawku Municipality; $\mathrm{TE}=$ mean annual temperature in ${ }^{\circ} \mathrm{C}$ in the Bawku Municipality; $\mathrm{SPH}=$ soil $\mathrm{pH}$; ORG = organic matter; $\mu=$ stochastic error term; and $\beta \mathrm{o}=$ intercept of the model.
The qualitative data recorded from the focus group discussions and structured interviews were analysed thematically based on different responses and used as vital elements of written text to better understand how farmers perceived the effect of climate variability on food crop production.

\section{Results and Discussion}

3.1. Rainfall Variation and Trend. Rainfall amount and timing influence the yield of crops. Low rainfall amounts can be detrimental to crop yield, particularly if dry periods occur during the critical stages of development of the crop [8]. The total annual amount of rainfall and the trend over the 15year period in the Bawku Municipality are displayed in Figure 2. The mean annual total rainfall from 1999-2013 is $901.9 \mathrm{~mm}$.

The total annual rainfall for the period ranged from a low of $217.9 \mathrm{~mm}$ in 2008 to a high of almost $1376 \mathrm{~mm}$ in 2007. Generally, the Mann-Kendall trend test of the rainfall dataset from 1999 to 2013 shows that at 5\% significance level, the trend is not statistically significant. Sen's estimate $(-26.567)$ indicates a decreasing trend (Figure 2). This is congruent to the findings of Asante and Amuakwa-Mensah [36] whose study of climate change and variability in Ghana reported decreasing trends of total rainfall amounts in northern Ghana. The variability in the year to year rainfall particularly towards the decreasing trend is a cautioning sign to the farming communities in the Municipality as this may adversely affect their livelihoods.

From Figure 3, the years 2005, 2008, 2010, and 2011 had a negative deviation signifying meteorological drought (period of below average precipitation) periods with the worst drought occurring in 2008. Global record of rainfall indicates a substantially high rainfall in 2005 and 2010 that resulted in severe floods in many parts of the world [37]. The positive deviation in 1999 and 2007 according to Paeth et al. [38] is attributable to the El Niño-Southern Oscillation (ENSO) effects which caused much rainfall in Sub Sahara Africa. This implies that severe floods might have occurred in 1999 and 2007 in the Bawku Municipality. Report by the Daily Graphic online [39] that floods occurred in the Upper West, Upper East, and the Northern Regions of Ghana confirms possibility of such earlier events. This may have affected agricultural activities in the Municipality. The estimated annual anomaly of rainfall (Figure 3 ) indicates that the total amount of annual rainfall varied substantially from year to year. This confirms the findings of Amikuzuno and Donkoh [23] that the prevailing evidence in the rainfall pattern observed in the semiarid regions of Africa is highly variable.

With regard to farmers' observations, all the respondents claim to have observed rainfall variation in the 15 years spanning 1999 to 2013. Approximately, 37\% of farmers were of the view that the amount of rainfall has reduced. Thirtyfive of the respondents representing $16.4 \%$ reported that the length of the rainy season had reduced. Interestingly, 28.5\% and $18.2 \%$ noticed an irregularity in the amount of rainfall 


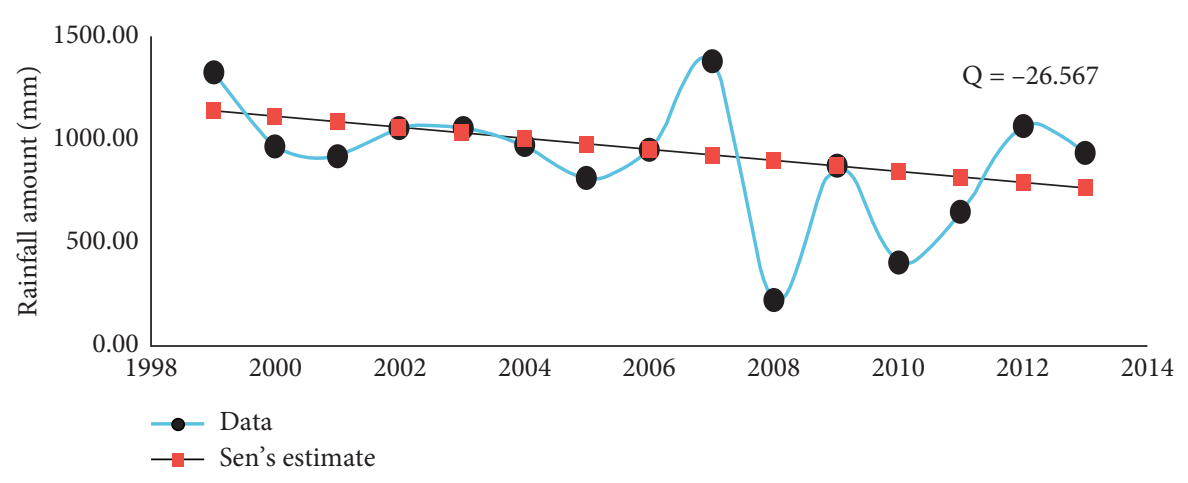

FIgURE 2: Total annual rainfall trend in the Bawku Municipality in the past 15 years.

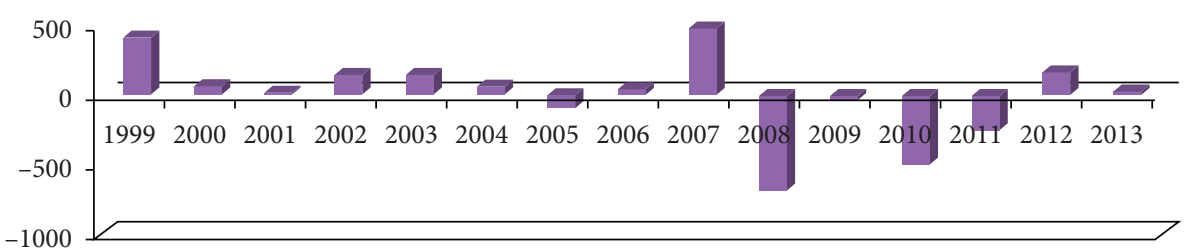

Figure 3: Annual rainfall deviations in the Bawku Municipality (1999-2013).

and a reduction in how long the rainy season lasts respectively (Table 2).

Similarly, key informants from SARI, MoFA, and GMA had also noted some pronounced variations in the rainfall pattern. According to the key informants, the rains either come earlier or later than expected. This was supported by a male farmer in Gentiga who pointed out in a focus group discussion that

(i) "When we were young, our wells and rivers were full in the rainy season which enabled us to get water in the dry season, drawing water from wells was not difficult but nowadays our wells and rivers have little water even in the rainy season... The rains do not fall as they used to. My biggest worry is its unpredictable nature" (FGD, 2014)

Generally, it was observed that respondents were much perturbed by the abnormality of the rainfall pattern in the Municipality which sometimes made it difficult to accurately predict when to start planting. The results presented show farmers observations are in line with the historical rainfall data for the 15-year period.

\subsection{Minimum and Maximum Temperature Variation and Trend}

3.2.1. Mean Annual Minimum Temperature. Figure 4 presents the mean annual variation/trend in minimum temperature in the Bawku Municipality. The mean annual minimum temperature from 1999 to 2013 fluctuated between $21.2^{\circ} \mathrm{C}$ and $23.4^{\circ} \mathrm{C}$ with a mean value of $22.7^{\circ} \mathrm{C}$. Sen's estimate $(-0.027)$ of the Mann-Kendall test indicates a significant decreasing trend in the mean annual minimum temperature (Figure 4) for the 15-year period (1999 to 2013).
However, the Mann-Kendall trend statistics for mean annual minimum temperature at $5 \%$ significance level was not statistically significant.

The mean minimum temperature for $1999\left(22.7^{\circ} \mathrm{C}\right)$ was found to be the same as the mean value $\left(22.7^{\circ} \mathrm{C}\right)$ for the 15 year period, showing no change for 1999. However, the years 2002 to 2006 and 2010 illustrate a significant increase in the minimum temperature with a positive deviation of between $0.2^{\circ} \mathrm{C}$ and $0.9^{\circ} \mathrm{C}$ above the baseline average (Figure 5). The rest of the years recorded negative deviations with the highest decrease of $1.53^{\circ} \mathrm{C}$ observed in 2012. This significant interannual variation in minimum temperature may have affected crop production in the Municipality. This is because a decrease in minimum temperatures affects night time plant respiration rate and possibly reduces crop yield [40]; meanwhile, when plants are exposed to higher minimum temperatures, it decreases their ability to grow and also reduces crop yield [41].

3.2.2. Mean Annual Maximum Temperature. The mean annual maximum temperature varied between $33.6^{\circ} \mathrm{C}$ and $35.8^{\circ} \mathrm{C}$ for the 15 -year period. The total mean maximum temperature from $1999-2013$ was $35.05^{\circ} \mathrm{C}$. The trend statistics of the Mann-Kendall test at 5\% significance level for the mean annual maximum temperature is not statistically significant. However, the observed trend of Sen's estimate $(-0.017)$ of the Mann-Kendall test for the mean annual maximum temperature over the 15 -year period portrays a decreasing trend (Figure 6).

Notwithstanding the above information, the mean maximum temperatures from 1999 to 2013 show distinctive interannual variation (Figure 6). In general, the maximum temperature decreased below the mean for the years 2000, 2004, 2007, 2008, 2009, 2012, and 2013, indicating that these 
TABLE 2: Respondents' observation of the manifestations of rainfall variation.

\begin{tabular}{|c|c|c|c|c|c|c|c|c|c|}
\hline \multicolumn{2}{|c|}{$\begin{array}{l}\text { Reduction in the } \\
\text { amount of rainfall }\end{array}$} & \multicolumn{2}{|c|}{$\begin{array}{l}\text { Reduction in the } \\
\text { length of the rainy } \\
\text { season }\end{array}$} & \multicolumn{2}{|c|}{$\begin{array}{l}\text { Irregularities in the } \\
\text { amount of rainfall }\end{array}$} & \multicolumn{2}{|c|}{$\begin{array}{l}\text { Irregularities in the } \\
\text { length of the rainy } \\
\text { season }\end{array}$} & \multicolumn{2}{|c|}{ Total } \\
\hline Freq & $\%$ & Freq & $\%$ & Freq & $\%$ & Freq & $\%$ & Freq & $\%$ \\
\hline 79 & 36.9 & 35 & 16.4 & 61 & 28.5 & 39 & 18.2 & 214 & 100 \\
\hline
\end{tabular}

Freq $=$ frequency.

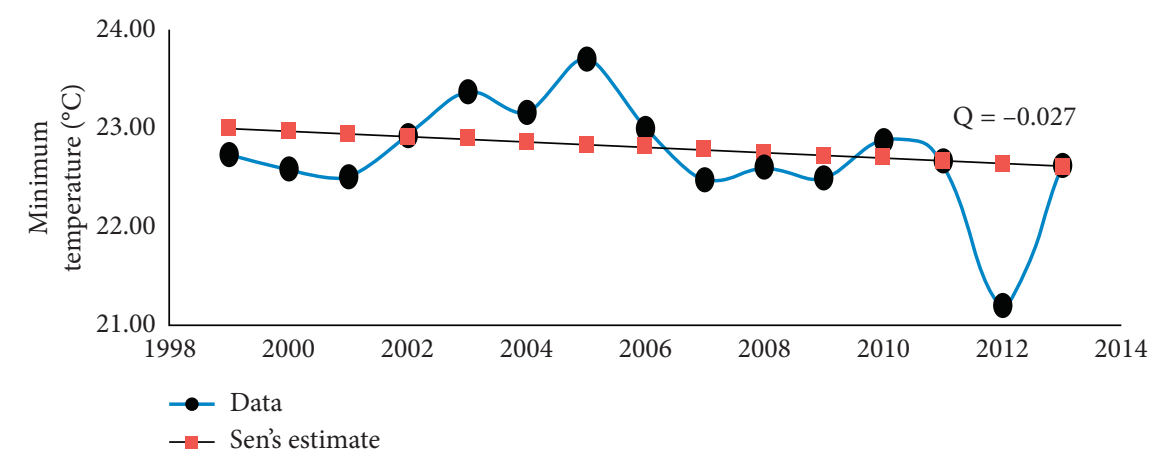

FIgURE 4: Mean annual trend in minimum temperature in the Bawku Municipality.

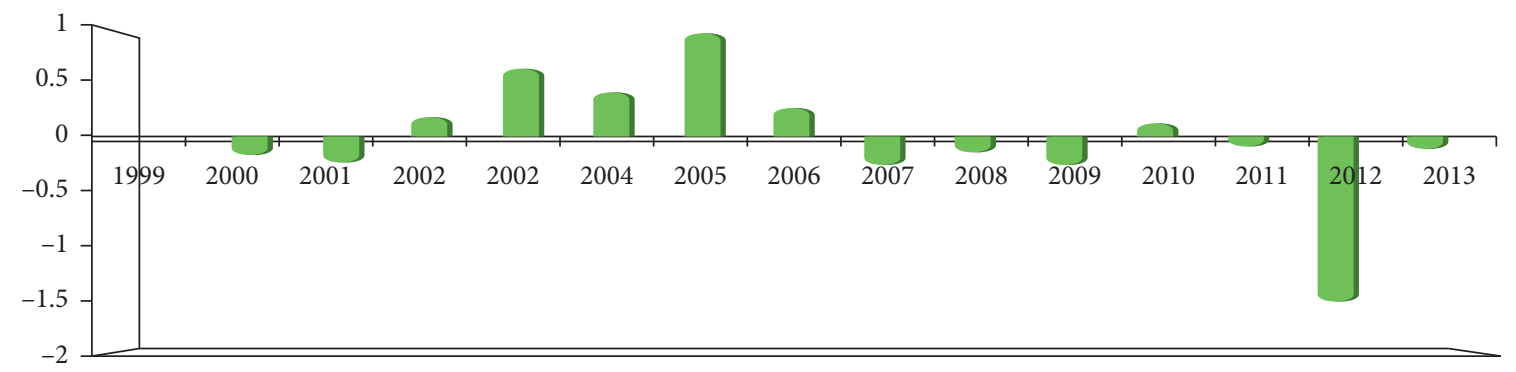

FIgUre 5: Mean annual deviation in minimum temperature $\left({ }^{\circ} \mathrm{C}\right)$ in the Bawku Municipality.

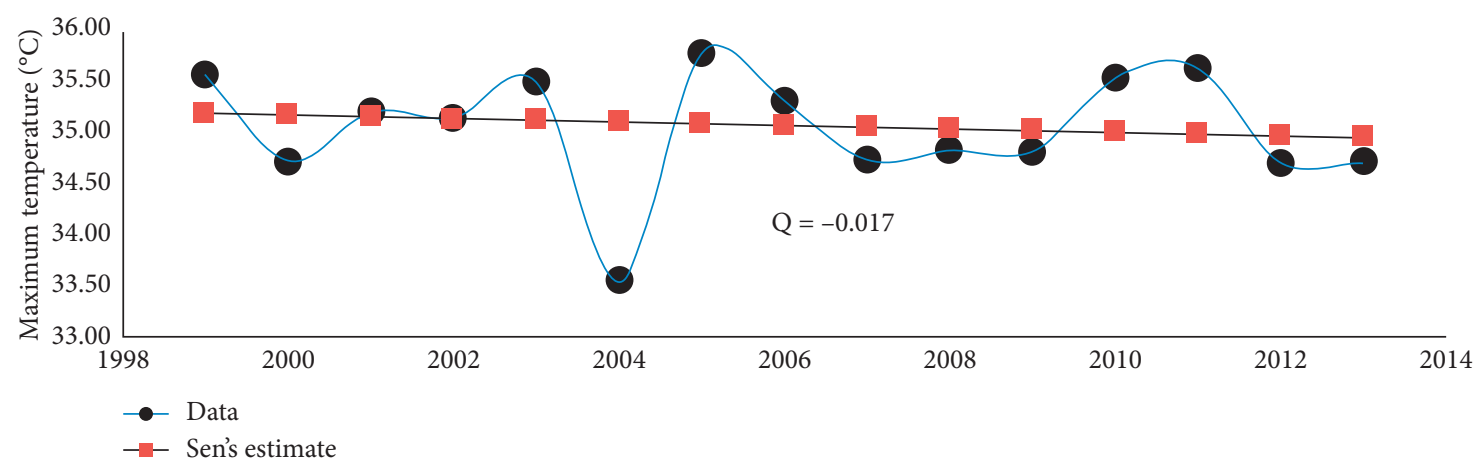

FIGURE 6: Mean annual trend in maximum temperature in the Bawku Municipality.

years were relatively cooler. The highest decrease occurred in 2004 with a decrease of $1.6^{\circ} \mathrm{C}$ below the baseline average. This confirms the report by Asante and Amuakwa-Mensah [36] that very cold winds were experienced in 2004. On the other hand, the year 2005 was marked as the warmest year with a positive deviation of $0.8^{\circ} \mathrm{C}$, which was greater than the global record of $0.62^{\circ} \mathrm{C}$. In addition, the mean annual deviation (Figure 7 ) shows more warm years than cold years 


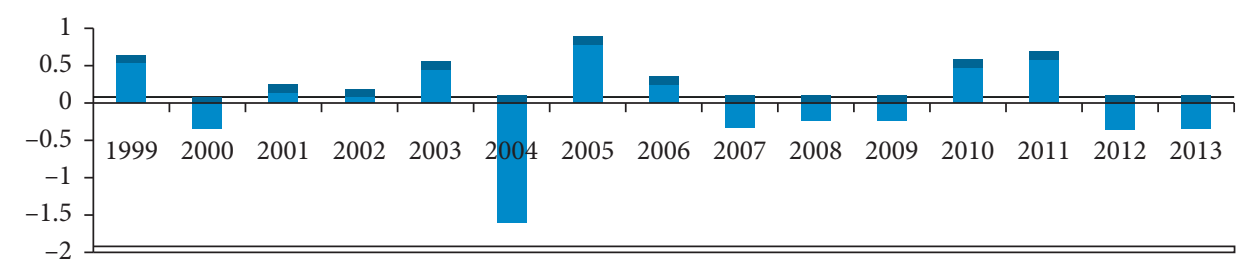

FIgUre 7: Mean annual deviation in maximum temperature $\left({ }^{\circ} \mathrm{C}\right)$ in the Bawku Municipality.

for the 15-year period. This has the tendency to cause fluctuations in crop output in the Municipality. Though, there are significant discrepancies in the interannual minimum and maximum temperature in the Municipality, the coefficient of variation (0.0155) for the mean annual temperature shows slight variation. This confirms the findings of Amikuzuno and Donkoh [23] that Northern Ghana has not significantly experienced notable temperature variation.

Superimposing the annual mean maximum temperature on the annual rainfall deviation for the 15 -year period shows that effective rainfall for food crop production in 2005, 2010, and 2011 was very low. This is because total annual rainfall for these years was below the baseline average while the temperature was high. Low annual rainfall coupled with high temperature on one hand results in poor organic matter content, making soil suitability for cropping one of the major problems in crop production [42]. This is likely to have had negative consequences on food crop production. On the other hand, the high rainfall coupled with low maximum temperature in 2007 and 2012 suggests that effective rainfall for these years were high. This may have benefited some crops. High temperature and high rainfall were recorded in 1999 and 2003. According to Shakoor et al. [43], high temperature and high rainfall are beneficial for all tropical crops but will produce negative effects if these climatic variables are increased too much in the future.

With respect to respondents' observations, the results indicate that most farmers $(86.4 \%)$ had observed temperature variation in the last 15 years. Majority of the farmers (76.1\%) who observed temperature variation believed that temperature has been increasing for the past 15 years (Figure 8), whereas $10.3 \%$ observed irregularities in temperature.

Though most farmers asserted that temperatures have increased, the observed mean annual temperature for the Municipality showed a decreasing trend. Farmers' observations are therefore at variance with the observed trend. Perhaps, the daily and monthly temperatures observed by the farmers were significant enough for them to notice some increase in temperature. It is clear from the results that farmers are aware of the temperature variation of the Municipality through their own experiences of the past.

3.3. Variation in Crop Yield (1999-2013). Figure 9 shows variation in the output figures of the three major food crops grown in the Municipality from 1999 to 2013. The first five years of the study period depict high production for the major food crops as compared to the second five years of the study period. Even though production was high for the first

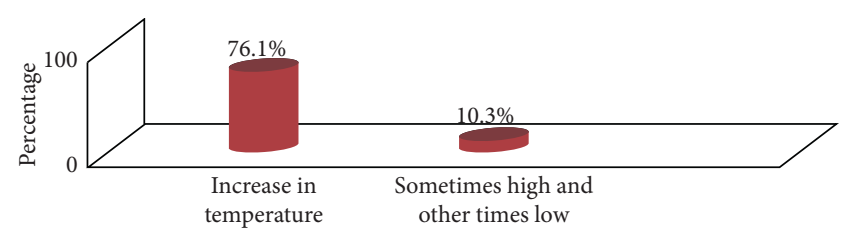

FIgURE 8: Respondents' opinion on the manifestations of temperature variation.

five years, there was a significant variation in the output of the food crops.

The low level of production in 2013, according to the Municipal Director of MoFA, was as a result of the carving out of a new district (Binduri District) from the Municipality. He explained that the splitting of the Bawku Municipality has reduced the production level of food crop since most food crop farmers are now part of the Binduri District. However, the year 2010 marked the worst season for maize and rice farmers when output levels fell tremendously. This is most likely due to the high maximum temperature and a low amount of rainfall recorded in 2010 [8, 44, 45]. Notwithstanding, the output of millet increased in 2010. Given that millet is drought-tolerant and grown as a famine crop $[8,45]$, most farmers may have shifted to the cultivation of millet when rainfall was expected to be below average in 2010. This reflects the assertion by a key informant from SARI that millet production has almost replaced maize in the Municipality due to the observed short and erratic rainfall pattern. This may have contributed to the increased millet production in 2010. The variation in maize $(\mathrm{CV}=0.4598)$, millet $(\mathrm{CV}=0.5653)$, and rice $(\mathrm{CV}=0.3860)$ for the 15 -year period could have implications for food security and livelihoods of farmers.

3.4. Effect of Climate Variability on Food Crop Production. We assessed and quantified the effects of climate variability on food crop production using a multiple regression model. The multiple regression results of the residual diagnostic test of assumptions are presented in Table 3.

The residual diagnosis for the test for heteroscedasticity for rice, maize, and millet using the Breusch-Pagan-Godfrey test did not show any heteroscedasticity at $5 \%$ significance level; thus, the variance of the error term is constant.

The result of the serial correlation in determining the autocorrelation shows that there is no correlation among the residuals in the regression model for maize (Zea mays L.), millet (Pennisetum glaucum L.), and rice (Oryza sativa L.). The test for normality using Jarque-Bera statistics also 


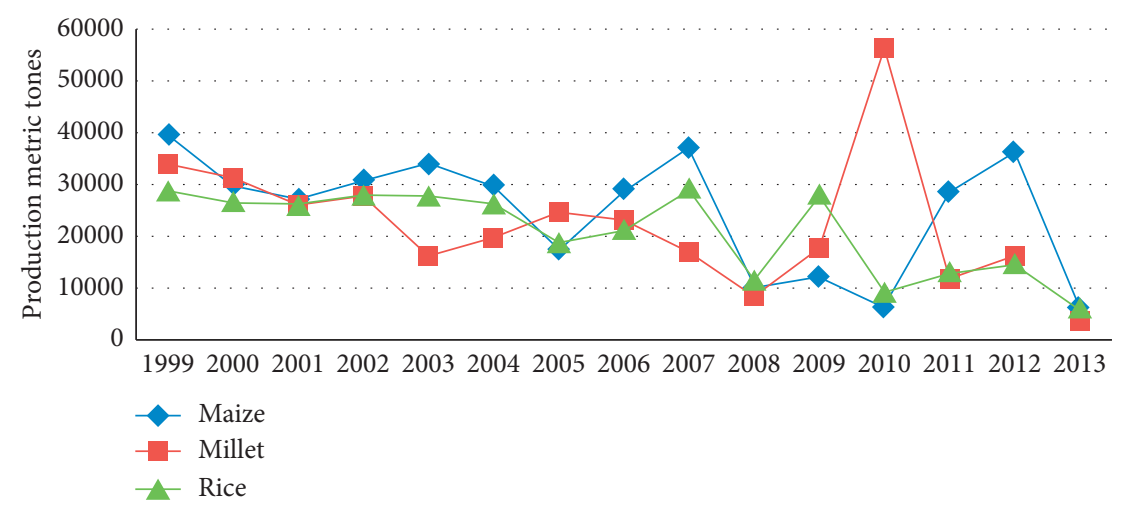

FIGURE 9: Major food crop production in the Bawku Municipality.

TABLE 3: Diagnostic test statistics for food crop production.

\begin{tabular}{|c|c|c|c|c|c|c|}
\hline \multirow{2}{*}{ Diagnosis } & \multicolumn{2}{|c|}{ Rice } & \multicolumn{2}{|c|}{ Maize } & \multicolumn{2}{|c|}{ Millet } \\
\hline & Test-statistics & Probability & Test-statistics & Probability & Test-statistics & Probability \\
\hline Heteroscedasticity & 3.31184 & 0.3460 & 0.4810 & 0.2140 & 5.8669 & 0.2109 \\
\hline Autocorrelation & 0.61641 & 0.4324 & 0.0869 & 0.7682 & 2.0130 & 0.1560 \\
\hline Normality & 3. 3790 & 0.1846 & 0.9865 & 0.6106 & 2.8627 & 0.2389 \\
\hline
\end{tabular}

indicates that the residuals are normally distributed. The results of the diagnostic test for rice, maize, and millet production, therefore, satisfied the assumptions of the multiple regression model. This implies that there are no problems that will significantly affect the regression results for rice, maize, and millet production.

3.4.1. Effect of Climate Variability on Rice (Oryza sativa L.) Production. The results of the log-linear regression model used for estimating the influence of climatic (mean annual temperature and annual rainfall) and nonclimatic (soil $\mathrm{pH}$ ) variables on rice production is presented in Table 4 .

The coefficient of determination $\left(R^{2}=0.5838\right)$ of the results shows that approximately $58.4 \%$ of the variation in the log of rice is explained by the log of average temperature, annual rainfall, and soil fertility. The remaining percentage (41.6\%) could be attributed to other factors such as seed varieties, method of cultivation, etc. The insignificant levels of temperature and rainfall could be attributed to the low variation in average temperature (Table 5) during the study period (1999-2013) and use of irrigation for rice production in the Sudan Savanna Zone $[24,46]$. However, the result indicates that soil $\mathrm{pH}$ is statistically significant at $5 \%$ $(p<0.0251)$ and positively influences rice production. This may be due to the desirable soil $\mathrm{pH}$ (5.5 to 6.5) for rice production in the Bawku Municipality. The result, therefore, implies that a $1 \%$ increase in soil $\mathrm{pH}$ potentially leads to a $6.6 \%$ increase in rice yield holding other variables constant. The estimation, therefore, shows that rice production in the Municipality for the 15-year period was largely dependent on soil pH. This result is similar to the findings of Azman et al. [47] who observed in their study that relative rice yield is affected by soil $\mathrm{pH}$. This suggests that growing rice in an
TABLE 4: Regression statistics for rice production.

\begin{tabular}{lcccc}
\hline Variable & Coefficient & $\begin{array}{c}\text { Standard } \\
\text { error }\end{array}$ & $\begin{array}{c}\text { T- } \\
\text { statistics }\end{array}$ & Probability \\
\hline Constant & -7.619448 & 21.26389 & 21.26389 & 0.7269 \\
LnaverageTemp & 1.077336 & 1.077336 & 0.170053 & 0.8681 \\
LnRainfall & 0.323560 & 0.232461 & 1.391894 & 0.1915 \\
Lnsoil-Ph & 6.644933 & 2.564687 & 2.590934 & $0.0251^{*}$ \\
\hline
\end{tabular}

$R$ squared $=0.5838$, adjusted $R$ squared $=0.4704$, and F-statistics $=5.1452$ $(p<0.0182) .{ }^{*}$ Regression is significant at the 0.05 level.

TABle 5: Summary statistics of climate variables and major food crop production.

\begin{tabular}{lccc}
\hline Variables & Mean & $\begin{array}{c}\text { Standard } \\
\text { deviation }\end{array}$ & $\begin{array}{c}\text { Coefficient of } \\
\text { variation }\end{array}$ \\
\hline Rainfall & 901.92 & 301.50 & 0.33429 \\
Temperature & 28.89 & 0.45 & 0.01545 \\
Maize & 24880.38 & 11440.62 & 0.4598 \\
Millet & 22172.45 & 12533.54 & 0.5653 \\
Rice & 20979.07 & 8097.14 & 0.3860 \\
\hline
\end{tabular}

area with low soil $\mathrm{pH}$ could have adverse effects on the output of rice. From the regression results, it could be confirmed that soil $\mathrm{pH}$ rather than rainfall and temperature was an influential factor determining the variation in rice yield in the Municipality from 1999 to 2013.

3.4.2. Effect of Climate Variability on Maize (Zea mays L.) Production. Table 6 presents the results of the multiple regression used for estimating the influence of annual rainfall, average temperature, and soil organic matter on maize yield. From the results, the F-statistic is statistically 
TABLE 6: Regression statistics for maize production.

\begin{tabular}{lcccc}
\hline Variable & Coefficient & $\begin{array}{c}\text { Standard } \\
\text { error }\end{array}$ & $\begin{array}{c}\text { T- } \\
\text { statistics }\end{array}$ & Probability \\
\hline Constant & 27.67440 & 28.20512 & 0.981184 & 0.3476 \\
LnaverageTemp & -3.913351 & 8.010983 & -0.488498 & 0.6348 \\
LnRainfall & 0.668053 & 0.271932 & 2.456692 & $0.0319^{*}$ \\
LnOrganicmatter & 1.872949 & 0.777664 & 2.408429 & $0.0347^{*}$ \\
\hline
\end{tabular}

$R$ squared $=0.6091$, adjusted $R$ squared $=0.5025$, and F-statistics $=5.7141$ $(p<0.0131) .{ }^{*}$ Regression is significant at the 0.05 level.

significant at the $5 \%$ level $(p<0.0131)$. This means that the explanatory variables specified in the maize production model are jointly significant.

The results show that about $60.9 \%\left(R^{2}=0.6091\right)$ of the variation in the log of maize is explained by the log of average temperature, annual rainfall, and organic matter. The remaining percentage $(39.1 \%)$ could be attributed to other factors such as seed varieties, method of cultivation, etc. The annual rainfall $(p<0.0319)$ and organic matter $(p<0.347)$ at $5 \%$ significance level are statistically significant and positively contribute to maize production. The result, therefore, implies that a $1 \%$ increase in soil organic matter results in a $1.9 \%$ increase in maize yield holding other variables constant. This means that maize production in the Municipality would be partly influenced by nonclimatic variables. The result also shows that every $1 \%$ increase in rainfall potentially leads to a $0.7 \%$ increase in maize production holding other variables constant. This also means that as rainfall increases, maize yield also increases. These validate the study objective on the influence of observed climatic trends on food crop production. However, the average temperature is not statistically significant at 5\% significance level. Thus, the estimation shows that maize production in the Municipality is principally dependent on rainfall and organic matter.

\subsubsection{Effect of Climate Variability on Millet (Pennisetum} glaucum L.) Production. Table 7 shows the results of the loglinear regression model used for estimating the influence of climatic (temperature and rainfall) and nonclimatic (organic matter) on millet production.

The F-statistics is statistically significant at $5 \%$ significance level $(p<0.0444)$. This implies that the explanatory variables specified in the millet production model, namely, annual rainfall, average temperature, and organic matter are jointly significant. From Table 7, about $50.6 \%\left(R^{2}=0.5060\right)$ of the variation in the log of millet is explained by the log of average temperature, annual rainfall, and organic matter. The remaining percentage (49.4\%) could be attributed to other factors such as seed varieties, method of cultivation, etc. The results further reveal that organic matter is statistically significant with a $p$-value of 0.0128 (Table 7). The implication is that, holding other variables constant, a $1 \%$ increase in organic matter potentially leads to a $2.6 \%$ increase in millet yield. The result corroborates the findings of Tunde et al. [45] and Amikuzuno and Donkoh [23] who noted that millet production in the Kwara State in Northern
TABLE 7: Regression statistics for millet production.

\begin{tabular}{lcccc}
\hline Variable & Coefficient & $\begin{array}{c}\text { Standard } \\
\text { error }\end{array}$ & $\begin{array}{c}\text { T- } \\
\text { statistics }\end{array}$ & Probability \\
\hline Constant & -5.155400 & 31.74246 & -0.162413 & 0.8739 \\
LnaverageTemp & 8.268311 & 9.015681 & 0.917103 & 0.3788 \\
LnRainfall & -0.043149 & 0.306036 & -0.140992 & 0.8904 \\
LnOrganicmatter & 2.595624 & 0.875195 & 2.965767 & $0.0128 *$ \\
\hline
\end{tabular}

R squared $=0.5060$, adjusted $R$ squared $=0.3712$, and F-statistics $=3.7552$ $(p<0.0444) . *$ Regression is significant at the 0.05 level.

Nigeria and Northern Ghana appear to be insensitive to low rainfall, respectively. Thus, a low level of rainfall does not necessarily reduce millet production. The estimation, therefore, shows that in the Municipality, millet production is highly dependent on organic matter and not rainfall and temperature which were found to be statistically insignificant in explaining the variation in millet output during the 15 -year period.

\subsection{Perceived Effects of Climate Variability on Food Crop Production}

3.5.1. Effects of Rainfall Variability on Food Crop Production as Perceived by the Farmers. To triangulate the secondary data results with primary data, farmers' experiences were also obtained (Figure 10). The results show that all the farmers perceived rainfall variability to adversely affect the production of their main staple crops. A 57 years old male respondent explained that

(i) "When I started farming, the rains usually came in the fourth and fifth months of the year (April/May) which was the time for land preparation (tilling) and sometimes for planting. This normally supported the cultivation of several crops. But these days, the rains come and go at any time. Sometimes the rains don't come until the eighth or ninth month of the year making it difficult to plant millet, sorghum, maize, rice and other crops. In fact, it is not easy to predict when the rains will come and stop. I am particularly worried about what will happen to my farming business in the future because that is what I depend on" (FGD, 2014).

Statistically, all the respondents (100\%) indicated that the manifestations of rainfall variability have affected the growing season in the past 15 years. Also, nearly all the respondents (93\%) were of the view that the variable nature of rainfall in the Municipality has reduced the length of the growing season while the remaining respondents (7\%) observed irregularities in how long the growing season lasts. All the respondents (7\%) who observed irregularities in the length of the growing season reported that crop yield had moderately reduced. More than $76 \%$ and $16 \%$ of those who reported of a reduction in the length of the growing season also reported that crop yields have severely and moderately reduced, respectively. The responses differed among the study communities. For instance, all the respondents in Gozesi and Gentiga pointed out that the shortened length of the growing season has severely reduced crop yields, whereas 


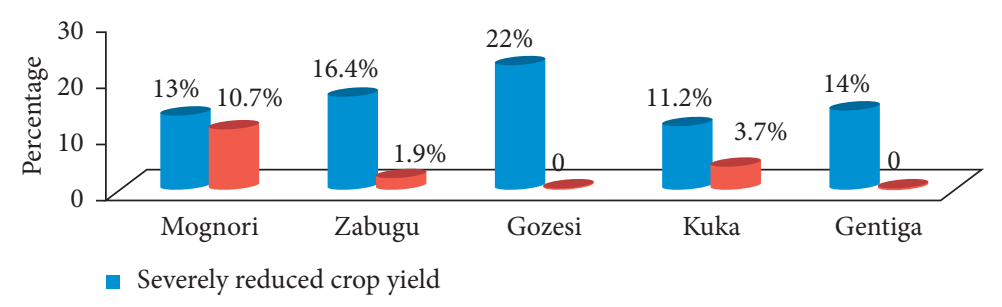

FIGURE 10: Respondents view on the effect of growing season on crop yield.

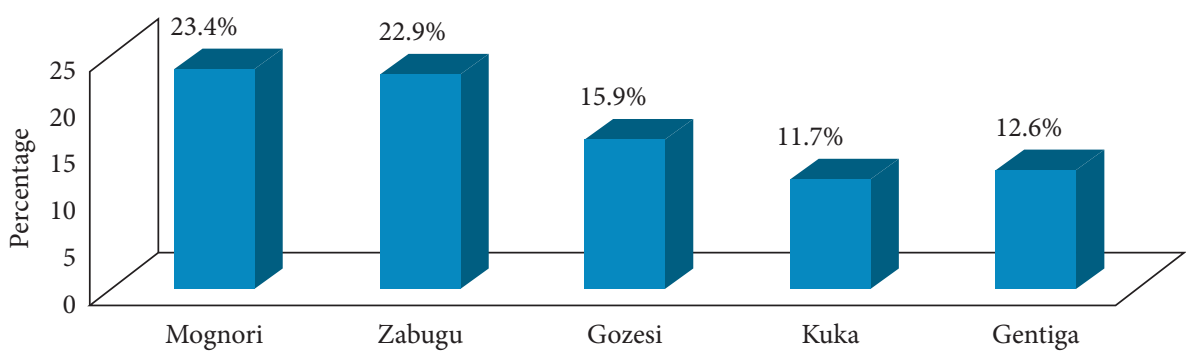

FIGURE 11: Respondents view on the effect of temperature variability on crop production.

respondents in Mognori (10.7\%), Zabugu (1.9\%), and Kuka $(3.7 \%)$ reported that crop yields have reduced moderately (Figure 10).

Although most respondents attributed the reduction in crop yield to a shorter growing season, discussants of focus groups from the selected communities acknowledged factors such as pests and diseases, wrong use of fertilizer, outmoded farm practices, inadequate funds, and intertribal conflicts as some of the major factors affecting crop production. The above nonclimatic factors coupled with low rainfall amounts and frequent droughts have the propensity to worsen food insecurity among the most vulnerable households in the Municipality [8, 45]. From the results, respondents' observations of the effect of rainfall variability on food crop production are in line with the regression results for maize production but inconsistent with rice and millet production. The inconsistency may be due to the influence of nonclimatic factors on food crop production as outlined by the farmers. Drawing on the results of the regression analysis and respondents' observations, it can be argued that rainfall variability for the 15 -year period had a significant influence on the variation of food crop production in the Municipality.

3.5.2. Perceived Effects of Temperature Variability on Food Crop Production. Also, we assessed farmers' perceived effects of temperature variability on food crop production. The results show that majority of the respondents $(86.4 \%)$ were of the view that temperature variability negatively affects crop production especially maize. Out of the $86.4 \%$ respondents who claimed that temperature variability had badly affected crop production, $23.4 \%, 22.9 \%, 15.9 \%, 11.7 \%$, and $12.6 \%$ were from Mognori, Zabugu, Gozesi, Kuka, and Gentiga respectively (Figure 11). These farmers asserted that there was a reduction in maize yield. Several studies have demonstrated similar results. Previous studies have observed that temperature increase above the requirement of between $30^{\circ} \mathrm{C}-34^{\circ} \mathrm{C}$ for maize production would reduce maize yield significantly [48-51].

In support of the above findings, interviews with officials of MoFA and SARI revealed that high temperatures during the main cropping season and dry season gardening lead to stunted growth and low yields of crops like maize, sorghum, onions, groundnut, and other vegetables. The official from SARI explained that high temperatures during the growing season negatively affects the respiration and transpiration of plants and in turn affects plant development and yield. This assertion is also buttressed by McCarl [52] and Fosu-Mensah [8] whose findings revealed that high temperatures influence the respiration needs and raises water demand for plant growth. Consequently, these factors will affect crop development and reduce crop yield [53].

Probing further to ascertain other possible factors responsible for low yield or crop failure, discussants of focus groups from the selected communities outlined poor farm practices, poor seeds, and misapplication of fertilizers as the key factors that may affect crop production. Despite the adverse effects of temperature variability on food crop production revealed by the survey, discussants of a focus group at Zabugu explained that millet thrives well under high temperatures with little amount of water. As a result, more millet is being produced in recent times. This finding supports previous studies on how millet and other droughttolerant crops are well adapted to high temperatures $[8,46,54]$.

Similarly, some discussants at Gentiga and Gozesi also argued that increased temperature during the harvest time helps reduce postharvest losses in cereals, particularly maize, and rice. The results revealed by the respondents on the effects of temperature variability on food crop production supports the idea that climatic variables may have both negative and positive implications on food crop production.

In general, the respondents in the Municipality seem to have noticed that temperature variability negatively affects 
maize production. However, the regression results indicated otherwise. The discrepancy between farmers' observations and the regression results may be due to the use of the mean annual temperature that mostly conceals daily extremes. In addition, the disparity may also be due to the influence of nonclimatic factors on food crop production as outlined by the farmers.

\section{Conclusion and Policy Implications}

This paper analysed how climate (rainfall and temperature) and nonclimatic variables (soil fertility using soil $\mathrm{pH}$ and organic matter) influence the production of agricultural staple crops of maize (Zea mays L.), millet (Pennisetum glaucum L.), and rice (Oryza sativa L.) in vulnerable rural communities in the Bawku Municipality of northern Ghana. The study revealed a decreasing trend with significant variation in the rainfall pattern while mean temperature showed a marginal decreasing trend with less variation over the 15 -year period. The multiple regression model revealed that rainfall and organic matter had a significant positive influence on maize production. Thus, maize production in the Municipality is mainly dependent on rainfall and organic matter. Similar to previous reports, mean temperature, and rainfall had no significant influence on millet and rice production in the Municipality. Nonetheless, organic matter and soil $\mathrm{pH}$ had a significant positive influence on millet and rice production, respectively. The prevailing evidence from the regression results suggests that temperature variation within the 15-year period had no significant influence on food crop production in the Municipality.

The results point to the need for effective ways to be adapted to a more uncertain rainfall pattern in the $\mathrm{Mu}$ nicipality. The results provide an opportunity to ensure sustainable crop production in the Municipality through a concerted effort between the Municipal Assembly, civil societies, NGOs, and farmers to negotiate and reach an agreement on pragmatic and effective adaptation measures. Not only will this option seek the concerns of farmers, it will also build the adaptive capacity of farmers in the Municipality. Provision of agricultural infrastructure such as irrigation facilities in the Bawku Municipality as well as improvement of existing ones could go a long way to address this critical challenge. This would encourage more farmers to farm during the long dry season. The provision of weather forecasts to farmers is central to farmers' adaptation because weather information has the tendency to influence farmers' decision on their farm operations. Finally, there is also the need for policy link by the government to promote the integration of indigenous knowledge and technologies with scientific knowledge to enable farmers adapt and develop agricultural resilience in the rapid climatic changes in Ghana.

\section{Data Availability}

Climate data used may be accessed from the Regional Meteorological Office, Bawku. Crop production figures may be accessed from the Municipal Directorate of the Ministry of Food and Agriculture, Bawku.

\section{Conflicts of Interest}

There are no conflicts of interest for this paper.

\section{References}

[1] Intergovernmental Panel on Climate Change, "Climate change 2007," in The Physical Science Basis. Contribution of Working Group I to the Fourth Assessment Report of the Intergovernmental Panel on Climate Change, S. Solomon, D. Qin, M. Manning et al., Eds., pp. 83-996, Cambridge University Press, Cambridge, UK, 2007.

[2] S. T. Kandji, L. Verchot, and J. Mackensen, Climate Change and Variability in the Sahel Region: Impacts and Adaptation Strategies in the Agricultural Sector, World Agroforestry Centre (ICRAF), Nairobi, Kenya, 2006.

[3] L. Scott, Climate Variability and Climate Change: Implications for Chronic Poverty, Overseas Development Institute, London, UK, 2008.

[4] Intergovernmental Panel on Climate Change, "Summary for policy makers," in The Assessment of Impacts, Adaptation and Vulnerability. Contribution of Working Groups II to the Fifth Assessment Report of the Intergovernmental Panel on Climate Change, C. B. Field, V. R. Barros, D. J. Dokken et al., Eds., pp. 1-32, Cambridge University Press, Cambridge, UK, 2014.

[5] Food and Agriculture Organization (FAO), Climate Change and Food Security: A Framework Document, Food and Agriculture Organization (FAO), Rome, Italy, 2008.

[6] K. Owusu and P. Waylen, "Trends in spatio-temporal variability in annual rainfall in Ghana (1951-2000)," Weather, vol. 64, no. 5, pp. 115-120, 2009.

[7] P. Rowhani, D. B. Lobell, M. Linderman, and N. Ramankutty, "Climate variability and crop production in Tanzania," Agricultural and Forest Meteorology, vol. 151, no. 4, pp. 449-460, 2011.

[8] B. Y. Fosu-Mensah, "Modelling maize (Zea mays L.) productivity and impact of climate change on yield and nutrient utilization in sub-humid Ghana," Ecology and Development Series, Vol. 87, ZEF, New York, NY, USA, 2012.

[9] T. M. Osborne and T. R. Wheeler, "Evidence for a climate signal in trends of global crop yield variability over the past 50 years," Environmental Research Letters, vol. 8, no. 2, pp. 1-9, 2013.

[10] A. M. Mohammed, T. Tena, P. Singh, and A. Molla, "Modelling climate change impact on chickpea production and adaptation options in the semi-arid North- Eastern Ethiopia," Journal of Agriculture and Environment for International Development, vol. 110, no. 2, pp. 377-395, 2016.

[11] A. Abdulai, "The challenges and adaptation to climate change by farmers in Sub-Sahara Africa," Agricultural Economics Research, Policy and Practice in Southern Africa, vol. 57, no. 2, pp. 28-39, 2018.

[12] K. R. Kumar, R. G. Ashrit, N. R. Deshpande, and J. W. Hansen, "Climate impacts on Indian agriculture," International Journal of Climatology, vol. 24, no. 11, pp. 13751393, 2004.

[13] M. V. K. Sivakumar, H. P. Das, and O. Brunini, "Impacts of present and future climate variability and change on agriculture and forestry in the arid and semi-arid tropics," Climatic Change, vol. 70, no. 1-2, pp. 31-72, 2005. 
[14] P. Jones and P. Thornton, "The potential impacts of climate change on maize production in Africa and Latin America in 2055," Global Environmental Change, vol. 13, no. 1, pp. 51-59, 2003.

[15] G. Yohe, R. S. J. Tol, and D. Murphy, "On setting near-term climate policy while the dust begins to settle," Energy \& Environment, vol. 18, no. 5, pp. 621-633, 2007.

[16] World Meteorological Organisation, Weather Climate and Food Security-Integrated Drought Management, World Meteorological Organisation, Geneva, Switzerland, 2001.

[17] E. L. Molua, "Climate variability, vulnerability and effectiveness of farm-level adaptation options: the challenges and implications for food security in Southwestern Cameroon," Environment and Development Economics, vol. 7, no. 3, pp. 529-545, 2002.

[18] O. Bazrafshan, H. Zamani, H. Ramezani Etedali, and S. Dehghanpir, "Assessment of citrus water footprint components and impact of climatic and non-climatic factors on them," Scientia Horticulturae, vol. 250, pp. 344-351, 2019.

[19] E. H. Bjergmark, S. G. Olesen, M. Mikkelsen, and K. A. Nielsen, Dyrkning af Grovfoder, P. R. Koch, Ed., pp. 77-97, Landbrugsforlaget Inc., Aarhus, Denmark, Forth edition, 2005.

[20] M. V. Odgaard, P. K. Bøcher, T. Dalgaard, and J. C. Svenning, "Climatic and non-climatic drivers of spatiotemporal maizearea dynamics across the northern limit for maize production-a case study from Denmark'," Agriculture, Ecosystems and Environment, vol. 142, no. 3-4, pp. 291-302, 2011.

[21] P. Antwi-Agyei, C. H. Quinn, S. G. K. Adiku et al., "Perceived stressors of climate vulnerability across scales in the Savannah zone of Ghana: a participatory approach," Regional Environmental Change, vol. 17, no. 1, pp. 213-227, 2017.

[22] E. Neumayer and T. Plümper, "The gendered nature of natural disasters: the impact of catastrophic events on the gender gap in life expectancy, 1981-2002," Annals of the Association of American Geographers, vol. 97, no. 3, pp. 551-566, 2007.

[23] J. Amikuzuno and S. A. Donkoh, "Climate variability and yields of major staple food crops in northern Ghana," African Crop Science Journal, vol. 20, no. 2, pp. 349-360, 2012.

[24] D. H. Acquah, "Farmers perception and adaptation to climate change: a willingness to pay analysis," Journal of Sustainable Development in Africa, vol. 13, no. 5, pp. 150-161, 2011.

[25] T. Dietz, D. Millar, S. Dittoh, F. Obeng, and E. Ofori-Sarpong, "Climate and livelihood change in north east Ghana.," in The Impact of Climate Change on Drylands with a Focus on West Africa, A. J. Dietz, R. Ruben, and A. Verhagen, Eds., pp. 149-172, Kluwer Academic Publishers, Dordrecht, Netherland, 2004.

[26] A. Oppong-Ansah, Getting the Fight against Floods Right in Ghana, Ghana News Agency, Accra, Ghana, 2011.

[27] A. J. Stanturf, M. L. J. Warren, S. Charnley et al., Ghana Climate Change Vulnerability and Adaptation Assessment, United States Forest Service, Washington, DC, USA, 2011.

[28] H. Nyantakyi-Frimpong, "Indigenous knowledge and climate adaptation policy in Northern Ghana," A Project of the Africa Initiative Backgrounder, United States Agency for International Development, Washington, DC, USA, 2013.

[29] Ghana Statistical Service, Population and Housing Census: Summary Report of Final Result, Ghana Statistical Service, Accra, Ghana, 2014.

[30] Z. Hochman, D. Gobbett, D. Holzworth et al., "Reprint of Quantifying yield gaps in rainfed cropping systems: a case study of wheat in Australia," Field Crops Research, vol. 143, pp. 65-75, 2013.

[31] V. Kasiulevičius, V. Šapoka, and R. Filipavičiūtè, "Sample size calculation in epidemiological studies," Gerontologija, vol. 7, no. 4, pp. 225-231, 2006.

[32] A. M. Tunde, "Perception of climate variability on agriculture and food security by men and women farmers," Ethiopian Journal of Environmental Studies and Management, vol. 4, no. 2, pp. 19-32, 2011.

[33] D. Balance, Assumptions in multiple regression: A tutorial, University of Calgary, Calgary, Canada, 2011.

[34] A. Onoja and E. N. Ajie, "Econometric analysis of food crops' response to climate variability and macroeconomic policies reforms in Nigeria (1978- 2009)'," Asian Journal of Agriculture and Rural Development, vol. 2, no. 3, pp. 487-497, 2012.

[35] S. Akpan, V. P. I. nimfon, J. U. Samuel, A. O. Edem, and E. O. Uwemedimo, "Determinants of credit access and demand among poultry farmers in Akwa Ibom state, Nigeria," American Journal of Experimental Agriculture, vol. 3, no. 2, pp. 293-307, 2013.

[36] F. A. Asante and F. Amuakwa-Mensah, "Climate change and variability in Ghana: Stocktaking," Climate, vol. 3, no. 1, pp. 78-99, 2015.

[37] National Aeronautics and Space Administration (NASA), Climate change: Vital Signs of the Planet, National Aeronautics and Space Administration (NASA), Washington, DC, USA, 2011.

[38] H. Paeth, A. H. Fink, S. Pohle, F. Keis, H. Mächel, and C. Samimi, "Meteorological characteristics and potential causes of the 2007 flood in sub-Saharan Africa," International Journal of Climatology, vol. 31, no. 13, pp. 1908-1926, 2011.

[39] Daily Graphic Online, Flood Disaster Profile of Ghana Since 1968, Daily Graphic Online, Accra, Ghana, 2015.

[40] J. L. Hatfield, K. J. Boote, B. A. Kimball et al., "Climate impacts on agriculture: implications for crop production," Agronomy Journal, vol. 103, no. 2, pp. 351-370, 2011.

[41] J. R. Welch, J. R. Vincent, M. Auffhammer, P. F. Moya, A. Dobermann, and D. Dawe, "Rice yields in tropical/subtropical Asia exhibit large but opposing sensitivities to minimum and maximum temperatures," Proceedings of the National Academy of Sciences, vol. 107, no. 33, pp. 1456214567, 2010.

[42] A. R. Nikoi, Human Geography for Senior High Schools, Aki Ola Publications, Accra, Ghana, 2010.

[43] U. Shakoor, A. Saboor, I. Baig, A. Afzal, and A. Rahman, "Climate variability impacts on rice crop production in Pakistan," Pakistan Journal of Agricultural Research, vol. 28, no. 1, pp. 19-27, 2015.

[44] K. J. Boote and T. R. Sinclair, "Crop physiology: significant discoveries and our changing perspective on research," Crop Science, vol. 46, no. 5, pp. 2270-2277, 2006.

[45] A. M. Tunde, B. A. Usman, and V. O. Olawepo, "Effects of climatic variables on crop production," Journal of Geography and Regional Planning, vol. 4, no. 14, pp. 708-714, 2011.

[46] Environmental Protection Agency, Ghana State of the Environment Report 2008, Environmental Protection Agency (EPA), Accra, Ghana., 2008.

[47] E. A. Azman, S. Jusop, C. F. Ishak, and R. Ismail, "Increasing rice production using different lime sources on an acid sulphate soil in Merbok, Malaysia," Pertanika Journal of Tropical Agricultural Science, vol. 37, no. 2, pp. 223-247, 2014.

[48] M. Ramadoss, C. J. Birch, P. S. Carberry, and M. Robertson, "Water and high temperature stress effects on maize production," in Proceedings of the 4th International Crop Science 
Congress, Brisbane, Australia, September 2004, http://www. cropscience.org.au.

[49] P. J. M. Cooper, K. P. C. Rao, P. Singh et al., "Farming with current and future climate risk: advancing a 'hypothesis of hope' for rain-fed agriculture in the Semi-Arid Tropics', Journal of Semi-Arid Tropical Agricultural Research, vol. 7, pp. 1-9, 2009.

[50] J. Gornall, R. Betts, E. Burke et al., "Implications of climate change for agricultural productivity in the early twenty-first century," Philosophical Transaction of the Royal Society B, vol. 365, no. 1554, pp. 2972-2989, 2010.

[51] D. B. Lobell, W. Schlenker, and J. Costa-Roberts, "Climate trends and global crop production since 1980," Science, vol. 333, no. 6042, pp. 616-620, 2011.

[52] B. A. McCarl, "United States' agriculture in the climate change sequence," http://www.texasclimate.org/Portals/6/Books/ ImpactTX/Ch6_McCarl.pdf, 2006.

[53] A. J. Challinor, T. R. Wheeler, P. Q. Craufurd, J. M. Slingo, and D. I. F. Grimes, "Design and optimisation of a large-area process-based model for annual crops," Agricultural and Forest Meteorology, vol. 124, no. 1-2, pp. 99-120, 2004.

[54] S. Kumar, A. K. Shukla, and H. V. Singh, "Intercropping of pearl millet and cowpea as rain-fed fodder crops," International Interdisciplinary Research Journal, vol. 4, no. 3, pp. 122-129, 2013. 